\title{
Impact of Annexin A3 expression in gastric cancer cells
}

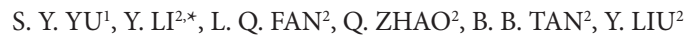 \\ ${ }^{1}$ The Third Hospital of Hebei Medical University, Shijiazhang, China; ${ }^{2}$ The Fourth Hospital of Hebei Medical University, Shijiazhang, China \\ *Correspondence: li_yong_hbth@126.com, suyangyu@hotmail.com
}

Received June 5, 2013 / Accepted September 5, 2013

\begin{abstract}
Annexin A3 participates in various biological processes, including tumorigenesis, drug resistance, and metastasis. The aim of this study was to investigate the expression of Annexin A3 in gastric cancer and its relationship with cell differentiation, migration, and invasion of gastric cancer cells. Annexin A3 expression in gastric cancer tissues was detected by quantitative real-time PCR and Western blotting. The proliferation of gastric cancer cells was measured by the MTT assay. Cell migration and invasion were determined via wound healing and transwell assays, respectively. Knock down of endogenous Annexin A3 in gastric cancer BGC823 cells was performed using siRNA technology. The expression of Annexin A3 was significantly upregulated in gastric cancer tissues, and negatively correlated with the differentiation degree. Silencing of endogenous Annexin A3 suppressed the proliferation, migration, and invasion of BGC823 cells. Additionally, the expression of p21, p27, TIMP-1, and TIMP-2 was upregulated, and the expression of PCNA, cyclin D1, MMP-1, and MMP-2 decreased in cells treated with Annexin A3-siRNA. Annexin A3 was upregulated in gastric cancer cells. Deletion of endogenous Annexin A3 significantly inhibited gastric cancer cell proliferation, migration, and invasion.
\end{abstract}

Key words: gastric cancer, annexin A3, siRNA, proliferation, migration

Gastric cancer is one of the most common malignancies worldwide; it is the fourth most common incidence and the second leading cause of cancer-related death $[1,2]$. Gastric cancer remains the deadliest cancer in Asian countries despite its declining incidence worldwide $[3,4,5]$. Currently, surgical resection is the most common treatment strategy; however, even surgery is limited because upon diagnosis, most cases are already in the advanced stages [6]. Patients receiving improved therapies $[7,8]$ for stomach cancer still have a poor prognosis, with a 5-year survival rate of less than 30\% [9]. Recent studies have found that several key molecules, such as NF-kB and PI3K, play important roles in the development of gastric cancer [10-11]. Annexin A3 is a member of $\mathrm{Ca}^{2+}$-regulated phospholipid-and membrane-binding proteins. Several studies have indicated that Annexin A3 is implicated in tumor development, metastasis, and drug resistance [12]. Annexin A3 may act as a tumor suppressor or tumor promoter depending upon the type of tumor cell and tissue. Annexin A3 has been shown to be upregulated [13] in prostate cancer, and downregulated in kidney and thyroid cancers [14, 15]. Increased expression of Annexin A3 enhanced the drug resistance of ovarian and liver cancers $[16,19]$, promoted the progression of pancreatic, rectal, and glandular cancers [17], and accelerated the metastasis of lung cancer [18]. Therefore, Annexin A3 may serve as an reliable target for cancer therapy and a biomarker for studying tumor development, infiltration, metastasis, and patient prognosis. In the present study, we investigated the expression of AnnexinA3 in gastric cancer and its relationship to the differentiation of cancer cells.

\section{Patients and methods}

Cell lines and cultures. Cancer cell lines MKN28, SGC7901, and BGC823, were purchased from Cell Resource Center of Life Sciences (Shanghai, China). All cell lines were cultured in RPMI 1640 medium (Gibco, Grand Island, NY, USA) supplemented with $10 \%$ FBS, 100 units/ml penicillin, and $10 \mathrm{mg} / 100 \mathrm{ml}$ streptomycin. Cells were maintained at $37^{\circ} \mathrm{C}$ in an incubator containing $5 \% \mathrm{CO}_{2}$. Cells were dissociated with $0.25 \%$ trypsin containing $0.02 \%$ EDTA, and were then passaged.

Patients and tissue specimens. Surgical tissue specimens were obtained from 25 patients with gastric cancer who underwent surgical resection of their tumors in the Fourth Clinical Medical College of the Hebei Medical University (China). This group consisted of 42 males and 33 females 
whose ages ranged from 54 to 68 years. None of the patients received radio/chemotherapy prior to surgery. Tumor tissues and adjacent normal mucosa (at least $3 \mathrm{~cm}$ away from the edge of tumor mass) were collected at a size of $1.0 \mathrm{~cm} \times 0.5$ $\mathrm{cm} \times 0.5 \mathrm{~cm}$. The tissue specimens were immediately frozen in liquid nitrogen and stored at $-80^{\circ} \mathrm{C}$.

Quantitative RT-PCR. Total RNA was isolated using TRIZOL reagent (Invitrogen, Carlsbad, CA, USA) according to the manufacturer's protocol. A total of $2 \mu \mathrm{g}$ total RNA was subjected to cDNA synthesis using Superscript II reverse transcriptase (Invitrogen). Two microliters of the reverse transcription product was used to detect the expression level of mRNA using $\beta$-actin gene as an internal reference control. Quantitative real-time PCR was performed using the SYBR Green RT-PCR Kit (Applied Biosystems, Foster City, CA, USA) in a total volume of $20 \mu \mathrm{l}$ containing $2 \mu \mathrm{l}$ of reverse transcription product, $5 \mathrm{pmol}$ of each primer, 10 $\mu \mathrm{l}$ of 2x SYBR Green mix (Applied Biosystems), and $0.4 \mu \mathrm{l}$ of a 1,000x diluted reference dye (Applied Biosystems). The primers [20] used to detect Annexin A3 expression were 5'-CAAATTCACCGAGATCCTGT-3' (forward) and 5'TGCTGGAGTGCTGTACGAAA-3' (reverse), to detect the $\beta$-actin expression were 5'-ACCACAGTCCATGCCATCAC-3' (forward) and 5'-TCCACCACCCTGTTGCTGTA-3' (reverse). The reactions were performed in an Applied Biosystems Prism model 7900HT Sequence Detection System with the following settings: Prior to amplification, an initial denaturation step was performed $\left(95^{\circ} \mathrm{C}\right.$ for $5 \mathrm{~min}$ ) ensuring complete denaturation of the DNA and activation of the Taq polymerase. This was followed by 45 cycles of denaturation for $30 \mathrm{~s}$ at $95^{\circ} \mathrm{C}$, annealing for $30 \mathrm{~s}$ at $60^{\circ} \mathrm{C}$, and elongation for $30 \mathrm{~s}$ at $72^{\circ} \mathrm{C}$. Fluorescence was detected after each cycle. All reactions were done in triplicate. Relative expression levels were normalized using the $\beta$-actin gene as an internal reference control. Data analysis was carried out using the $2^{-\Delta \Delta \mathrm{CT}}$ method to calculate the expression levels.

Western blotting. Cellular protein was extracted with lysis buffer and protease inhibitors (Beyotime, China). Sixty micrograms of protein from each sample were separated on $12 \%$ SDS-PAGE gels, and electroblotted to PVDF membranes (Roche, Basel Switzerland). Membranes were blocked in Tris-buffered saline with $0.1 \%$ Tween-20 (TBS-T) containing $5 \%$ non-fat milk for $1 \mathrm{~h}$ at room temperature, followed by an incubation with primary antibodies, Annexin A3, PCNA, p21, p27, cyclin D1, TIMP-1, TIMP-2, MMP-1 and MMP-2 (All of these antibodies were purchased from Santa Cruz, USA) at $4^{\circ} \mathrm{C}$ overnight. After several washes with TBS-T, blots were incubated with horseradish peroxidase-conjugated secondary antibody for $1 \mathrm{~h}$ at room temperature. $\beta$-actin protein level was used as a control for equal protein loading.

Annexin A3-siRNA transfections. Small interfering RNAs (siRNAs) targeting Annexin A3 were designed according to the guidelines of the "Dharmacon siDESIGN Center" (www. dharmacon.com). The sequences of each siRNA pairs were as follows: siRNA\#1 5'-GAGACGAAAGCCUGAAAGUdTdT-
3' and 5'-ACUUUCAGGCUUUCGUCUcdTdT-3, siRNA \#2, 5'-GGAGAAUUAUCUGGGCAUUdTdT - 3 ' and 5'AAUGCCCAGAUAAUUCUCcdTdT-3', and non-target siRNA (NS siRNA) \#3, 5'- ACUCUAUCUGCACGCUGACUU-3' and 5'-PGUCAGCGUGCAGAUAGAGUUU-3'. These siRNAs were dissolved in an RNase-free solution at a concentration of $20 \mu \mathrm{mol} / \mathrm{l}$. Cells were cultured in six-well plates for $24 \mathrm{~h}$, and washed with RPMI 1640 prior to transfection. Cells were divided into control, NS-siRNA and Annexin A3 siRNA groups. The control group was treated with Lipofectamine 2000 only. The NS-siRNA group was transfected with non-target siRNA, and the Annexin A3 siRNA group was transfected with target Annexin A3 siRNA. Transient transfection of Annexin A3 siRNA was performed using Lipofectamine 2000 (Invitrogen) according to the manufacturer's instructions. After transfection for $24 \mathrm{~h}$, the transfection efficiency was evaluated.

MTT cell proliferation assay. BGC823 cells were incubated in 96-well plates at a density of $6 \times 10^{4}$ cells $/ \mathrm{ml}$. When the cell density reached $70 \%$ confluence, Annexin A3 siRNA and control siRNA were transfected. At the end of the experiment, $20 \mu \mathrm{l}$ of methyl thiazolyl tetrazolium (MTT, $5 \mathrm{mg} / \mathrm{ml}$ ) was added to each well and incubated for another $4 \mathrm{~h}$. The medium was then discarded followed by addition of $150 \mu \mathrm{l}$ dimethyl sulfoxide (DMSO) and shaking at room temperature for $15 \mathrm{~min}$. Absorbance was recorded at $490 \mathrm{~nm}$ using a microplate reader.

Scratch test. Cells were seeded in a 6-well plate at a density of $1 \times 10^{6} \mathrm{cells} /$ well. Annexin A3 and control siRNAs were transfected under the aforementioned conditions. When cultured cells reached $100 \%$ confluence, media were discarded and the cells were washed with PBS. A thin-line scratch between the cells was created with a sterile pipette tip. Cell wound healing was observed by microscopy. The number of cells that crossed the scratch was counted in five arbitrary visual fields. The experiment was repeated three times.

Cell invasion assay. For invasion assays, transwell chambers ( $8 \mu \mathrm{m}$ pore size, polycarbonate filters, $6.5 \mathrm{~mm}$ diameter; Corning Costar, Corning, NY, USA) were coated with $100 \mu \mathrm{l}$ growth-factor-reduced Matrigel. BGC823 cells were suspended in a six-well plate at a density of $1 \times 10^{6}$ cells per $\mathrm{ml}$ or per well. Annexin A3 siRNA and control siRNA were transfected under the aforementioned conditions. After $24 \mathrm{~h}$, cells were dissociated with $0.25 \%$ trypsin containing $0.02 \%$ EDTA, after which $200 \mu \mathrm{l}$ of $\left(1 \times 10^{6} \mathrm{cells} / \mathrm{ml}\right)$ were incubated in the upper chamber, which was placed in a 24 -well plate. The lower chamber was added with RPMI 1640 medium containing $10 \%$ fetal calf serum. After a 24 -h incubation, non-invading cells on the top of the membrane were removed by scraping. The transwell membranes were fixed in methanol for $10 \mathrm{~min}$ and stained with crystal violet. Cells on the underside of the membranes that had invaded the Matrigel were counted under a microscope. Five arbitrary visual fields were counted for each membrane.

Statistical analysis. The results were expressed as the mean \pm standard deviation. Statistical analysis was performed with 
SPSS software version 13.0. P values less than 0.05 were considered statistically significant.

\section{Results}

Expression of Annexin A3 in gastric cancer tissues and adjacent normal mucosa. In order to illustrate the role of Annexin A3 in gastric cancer, RT-PCR and Western blotting were applied to detect Annexin A3 expression in clinical samples of gastric cancer and adjacent normal mucosa. As shown in Figure $1 \mathrm{~A}$, the $28 \mathrm{~S}$ to $18 \mathrm{~S}$ rRNA ratio was $2: 1$. Annexin A3 mRNA expression was significantly higher in cancer tissues compared to normal tissues ( $p<0.05$, Fig. $1 B$ ), and the protein level of Annexin A3 was consistent with mRNA expression (Fig. 1C). These results showed that Annexin A3 is upregulated in gastric cancer tissues, indicating that it may play an important role in the development of gastric cancer.

Correlation of Annexin A3 expression with gastric cancer differentiation. To understand the relationship between An-

A

RNA

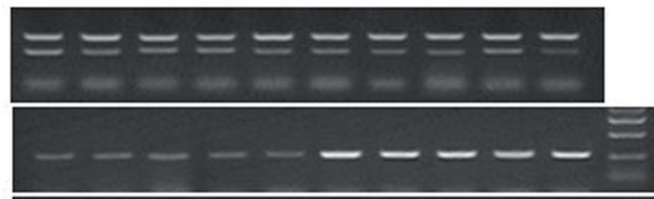

Annexin $\mathrm{A} 3$

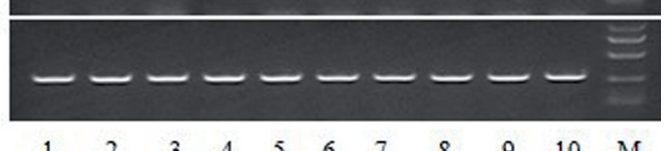

$\beta$-actin

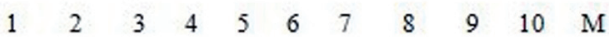

B

Annexin $\mathrm{A} 3$

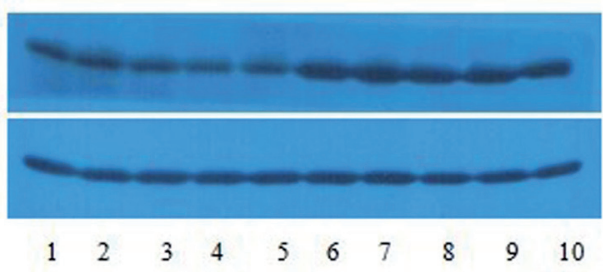

C

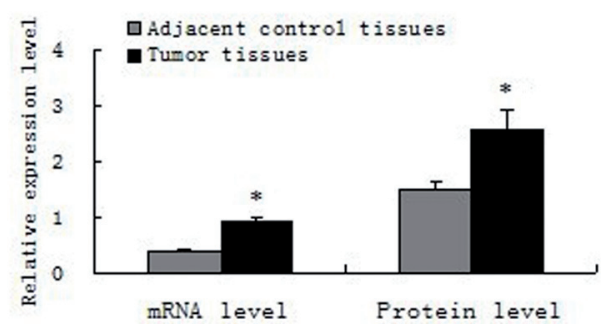

Figure 1. Expression of Annexin A3 in gastric cancer and normal tissues. Clinical samples of gastric carcinomas as well as adjacent control normal tissues were obtained and subjected to semi-quantitative RT-PCR (A) and Western blot analysis (B) to determine the expression of Annexin A3. (A) and (B), 1-5: Adjacent control tissues; 6-10: gastric carcinoma tumor tissues. Relative mRNA and protein expression levels are shown in (C). Values are shown as mean $\pm \mathrm{SD}, \mathrm{n}=5$ in each group. ${ }^{\star} \mathrm{P}<0.01$ versus control group. Data shown are representative images from at least three independent experiments. nexin A3 and gastric cancer, we investigated the correlation between Annexin A3 expression and the different stages of gastric cancer using real-time quantitative PCR and Western blot analyses. Annexin A3 mRNA and protein levels significantly differed according to the different stages and grades of gastric cancer tissues and cell lines (Fig. 2A, 2C). The higher the degree of differentiation, the lower the expression of both Annexin A3 mRNA and protein (Fig. 2B), indicating that Annexin A3 expression negatively correlates with the higher degrees of gastric cancer differentiation. These results further demonstrated the important function of Annexin A3 in the pathological process of gastric cancer.

Effect of siRNA on Annexin A3 expression in BGC823 cells. To further investigate the impact of Annexin A3 on gastric carcinogenesis, we employed siRNA techniques. Three pairs of siRNAs targeting Annexin A3 were designed and

A

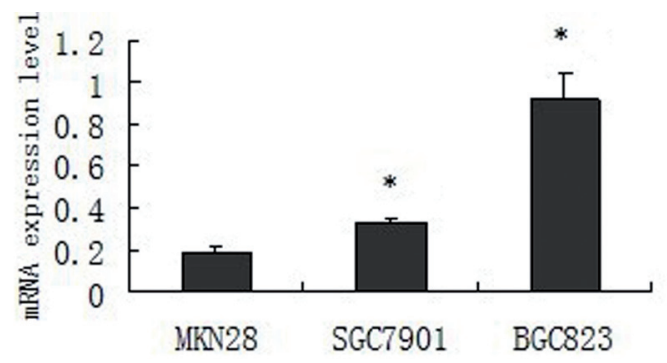

B

Annexin A3

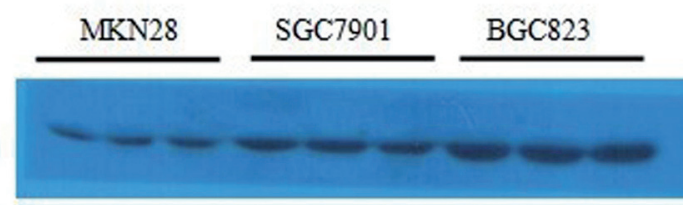

$\beta$-actin

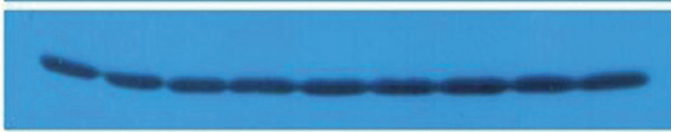

C

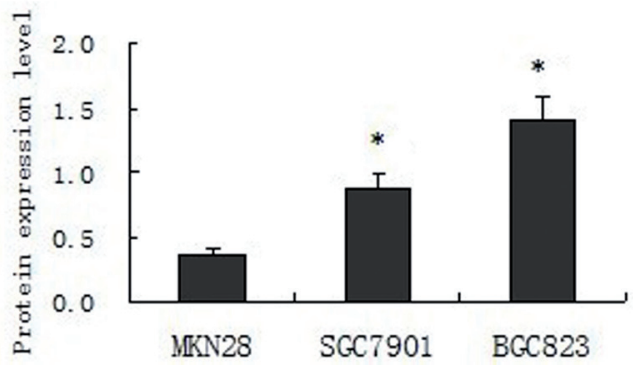

Figure 2. Annexin A3 expression is different in differentiated gastric cancer cell lines. Three gastric cancer cell lines with different levels of differentiation levels were cultured: MKN28 (well differentiated), SGC7901 (moderately differentiated), and BGC823 (poorly differentiated). The three cell lines were subjected to quantitative RT-PCR (A) and Western blot analysis (B) to determine Annexin A3 expression. Relative protein expression levels are shown in $(C)$. Values are shown as mean $\pm S D, n=3$ in each group. ${ }^{\star} \mathrm{P}<0.01$ versus $\mathrm{MKN} 28$ cells. Data shown are representative images from at least three independent experiments. 
transfected into BGC823 gastric cancer cells. Cells transfected with NS-siRNA were used as non-target siRNA controls. As shown in Fig 3, the expression of Annexin A3 was reduced by Annexin A3 siRNAs transfection in both mRNA and protein levels, while NS- siRNA did not change Annexin A3 expression (Fig.3 A, B), suggesting that that Annexin A3 siRNAs efficiently inhibited the transcription and translation of endogenous Annexin A3. The most reduced expression of Annexin A3 was found in siRNA-2-transfected BGC823 cells, with an inhibition of approximately $90 \%$ compared to the NS-siRNA group. In order to determine if there were any off-target effects from transfection of Annexin A3-siRNA, the

A

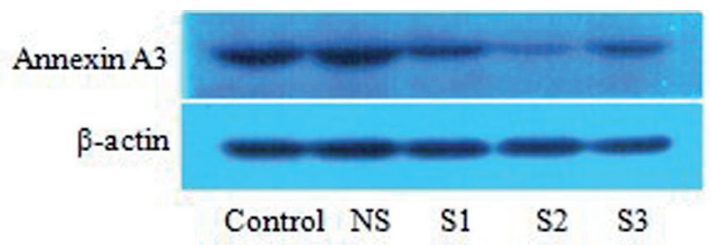

B

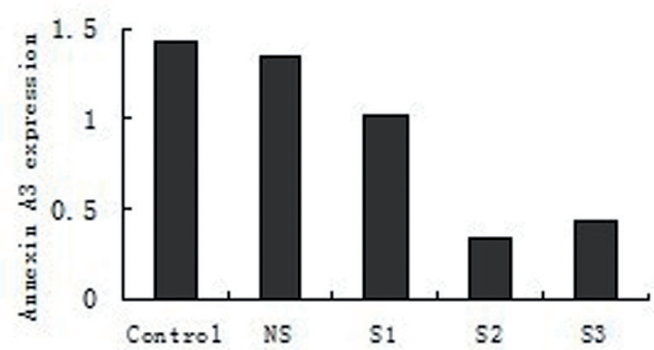

C

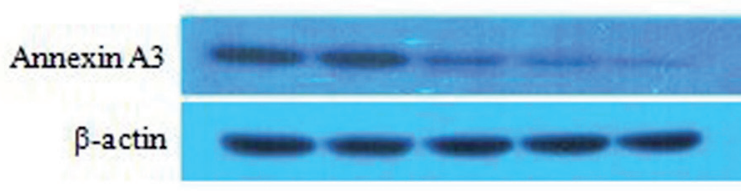

D

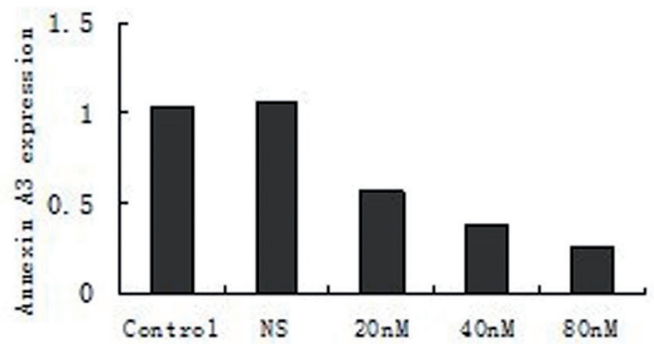

Figure 3. Annexin A3 siRNA downregulated Annexin A3 expression in BGC823 cells. Cells were transfected with different sequences of Annexin A3 siRNA (S1, S2, S3) or NS-siRNA (A), and cells were transfected with different concentrations of Annexin A3 siRNA-2 sequences for 24 hours (C). Expression of Annexin A3 was identified by Western blotting. Expression levels are represented as columns in (B) and (D). Data shown are representative images from at least three independent experiments. expression levels of several other Annexin family members, including Annexin A2, Annexin A5, and Annexin A7, were examined. The results confirmed that Annexin A3-siRNA2 did not affect the expression levels of the other Annexin family members. Further studies using Annexin A3 siRNA-2 showed that this inhibition is dependent on the concentration of siRNA used, the inhibition demonstrated at $80 \mathrm{nM}$, more than $95 \%$ of Annexin A3 expression was inhibited compared to the NS-siRNA (Fig. 3A, B).

Effect of Annexin A3 siRNA on the proliferation of BGC823 cells. BGC823 cells were transfected with $80 \mathrm{nM}$ Annexin A3 siRNA-2 for different periods of times or different concentrations ( $20 \mathrm{nM}, 40 \mathrm{nM}, 80 \mathrm{nM}$ ), followed by the MTT assay. As shown in Figure 4A and 4B, cell proliferation was time- and dose-dependently inhibited by siRNA treatments, while NS-siRNA had no significant effect on cell proliferation compared to cells treated with Lipofectamine alone $(\mathrm{p}>0.05)$. In addition, real-time quantitative PCR and Western blot analysis showed that the expression of $\mathrm{p} 21$ and p27 was significantly upregulated, while expression of PCNA and Cyclin D1 was significantly downregulated in BGC823 cells transfected with $80 \mathrm{nM}$ of siRNA, compared to cells treated with NS-siRNA (Fig. 4, C, D and E). These results indicated that suppression of endogenous Annexin A3 reduced cell proliferation.

Effect of siRNA on the invasion and migration of BGC823 cells. Next, we performed invasion and migration assays in cells treated with different concentrations of $80 \mathrm{nM}$ Annexin A3-siRNA-2 using the scratch test and transwell migration assay, respectively. As shown in Figure 5A, B and $\mathrm{C}$, the migration and invasion of cells treated with Annexin A3-siRNA-2 decreased compared to cells treated with NSsiRNA ( $\mathrm{p}<0.05$ ), while NS-siRNA had no significant effect on either cell invasion and migration compared to cells treated with Lipofectamine alone ( $p>0.05)$. Since tissue inhibitors of metalloproteinases (TIMP-1 and TIMP-2) play key roles in tumor progression and metastases, we further investigated the expression of TIMP- 1 and TIMP-2 in cells treated with siRNA by real-time quantitative PCR and Western blotting analysis. We found that TIMP-1 and TIMP-2 expression was significantly upregulated, while MMP-1 and MMP-2 expression was significantly downregulated in BGC823 cells transfected with $80 \mathrm{nM}$ Annexin A3-siRNA-2 compared to cells treated with NS siRNA (Fig. 5D, E and F). These results indicated that Annexin A3 promoted gastric cancer invasion and migration, and its suppression inhibited cell invasion and migration.

\section{Discussion}

In the present study, we found that Annexin A3 is upregulated in gastric cancer and its expression negatively correlates with the pathological differentiation of gastric carcinoma. Interestingly, the proliferation activity and invasion/migration abilities of gastric cancer cells were significantly reduced by deletion of endogenous Annexin A3, suggesting that upregulation of Annexin A3 expression promotes cell proliferation and 
A

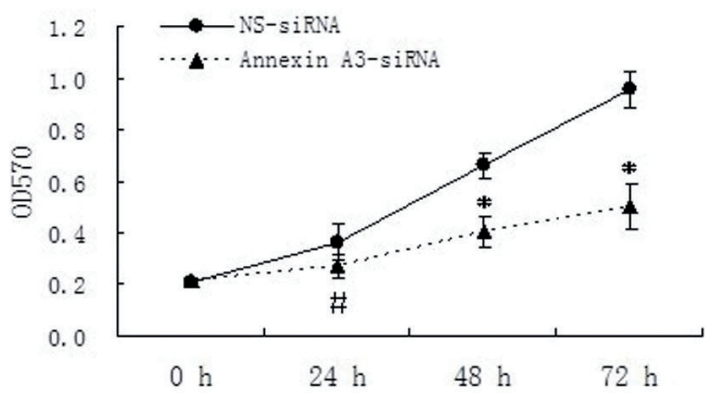

B

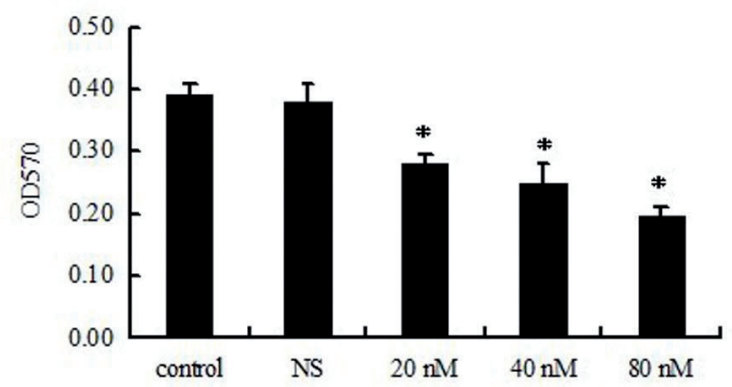

$\mathrm{C}$

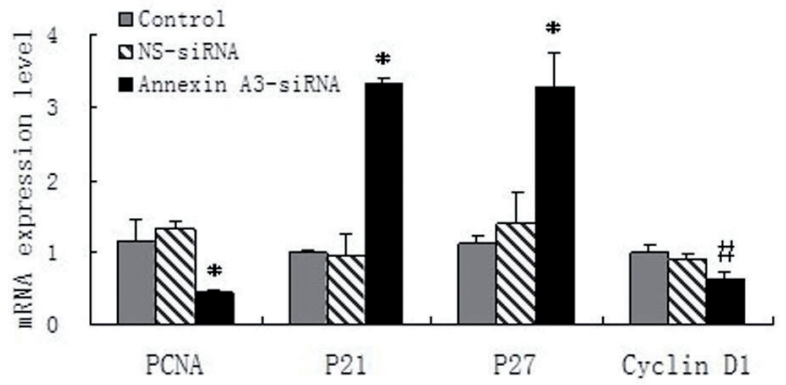

$\mathrm{D}$

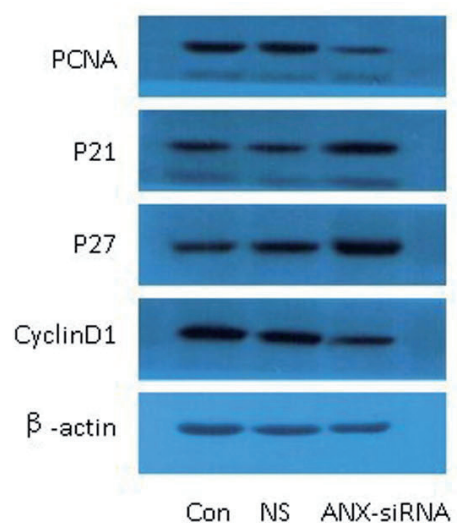

Figure 4. Effects of Annexin A3 siRNA-2 on the migration and invasion of BGC823 gastric cancer cells. Cells were transfected with $80 \mathrm{nM}$ Annexin A3 siRNA-2 for different times (A) or different concentrations for $24 \mathrm{~h} \mathrm{(B)}$ and then subjected to MTT assays to detect cell proliferation activity. Cells were transfected with $80 \mathrm{nM}$ Annexin A3 for $24 \mathrm{~h}$, quantitative RT-PCR (C) and Western blot analysis (D) to detect mRNA or protein levels of proliferationrelated genes, respectively. Protein expression levels are represented as columns in $(\mathrm{E}) .{ }^{\star} \mathbf{P}<0.01$ and $\# \mathbf{P}<0.05$ versus the values of the NS-siRNA group. Data shown are representative images from at least three independent experiments.

invasion/migration in gastric cancer. This study provides an important scientific basis for further clarifying gastric cancer pathogenesis and target gene therapy.

Annexin, one of the calcium-dependent phospholipidbinding proteins, is mainly located in the cytoplasm, and represents up to 1-2\% of total protein. Annexins exists in both a soluble form and a form combined with components of the cytoskeleton or proteins that mediate interactions between the cell and the extracellular matrix [22]. Annexins are classified into subgroups A (in mammalians), B (in invertebrates), $\mathrm{C}$ (in fungi and some groups of unicellular eukaryotes), D (in plants), and E (in protists) [23]. It has been shown that disorders of Annexin expression are indirectly linked to different human diseases, such as rheumatoid arthritis, lung cancer, and diabetes [24-25]. The expression level of Annexin is closely related to the proliferation, differentiation, and invasion/migration of tumors as well as the clinical stages of tumors $[12,20]$, and therefore has recently become a hot spot in the tumor research field. Human Annexin A3 genes are dispersed throughout the genome on chromosomes 4 q13-q22, including the two main isoforms of $33 \mathrm{kD}$ and $36 \mathrm{kD}$ [20]. Many studies have shown that changes in Annexin A3 expression have an important impact on the onset, development, drug resistance, and metastasis of tumors [12-18, 26]. The expression of Annexin A3 in carcinoma tissues is also closely associated with cancer type. For example, Annexin A3 expression is upregulated in ovarian cancer, and presents a positive relationship with drug resistance. However, this marker was downregu- 
A

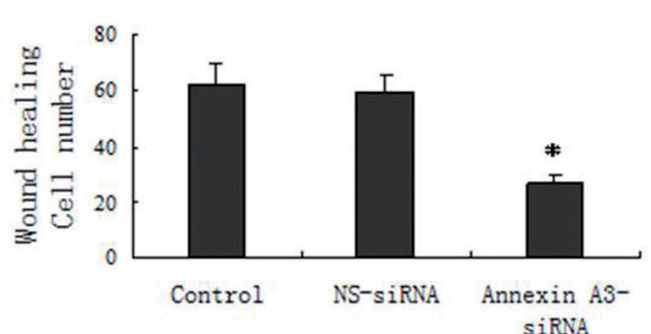

$\mathrm{B}$

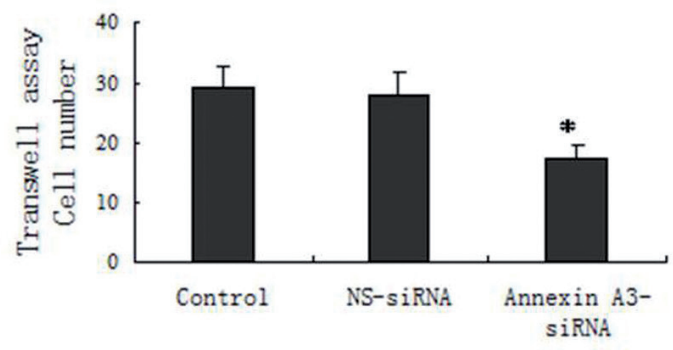

$\mathrm{E}$

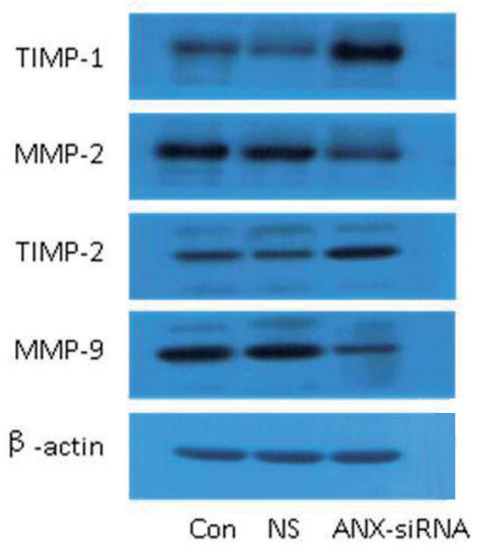

$\mathrm{C}$

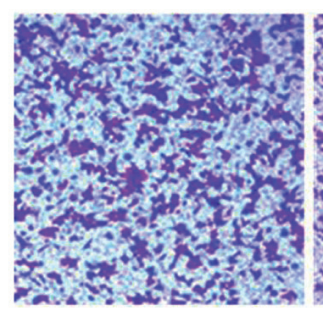

Control

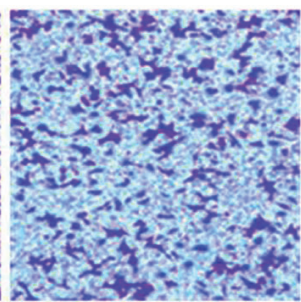

NS-siRNA

ANX3-SIRNA

$\mathrm{D}$

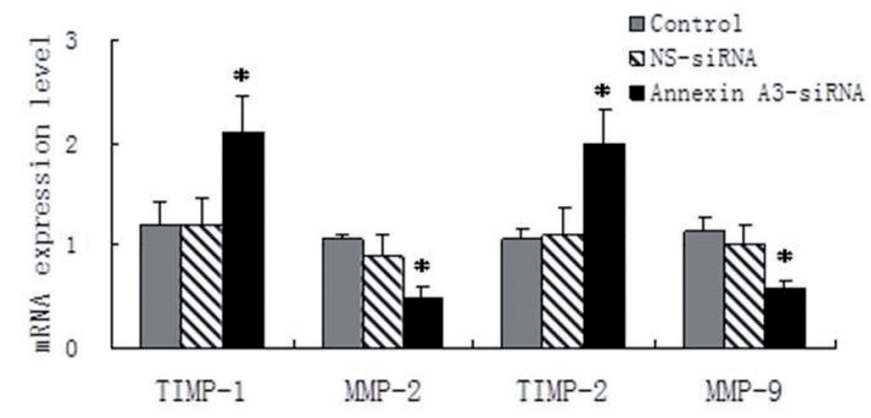

$\mathrm{F}$

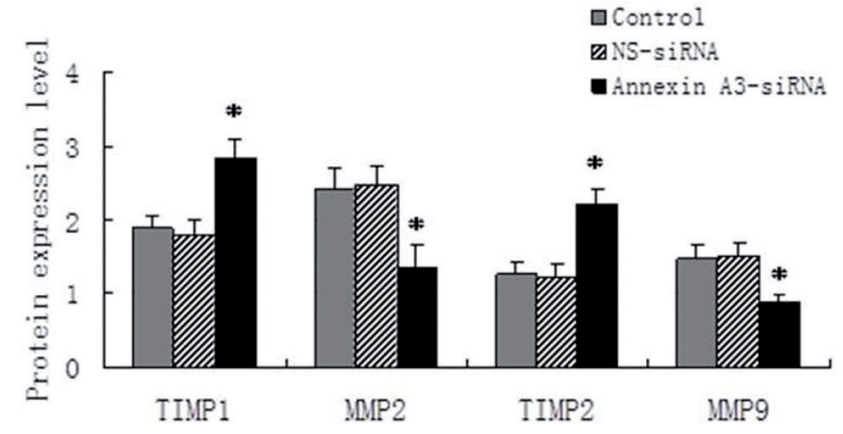

Figure 5. The effects of Annexin A3 over-expression on the migration and invasion of gastric cancer cell BGC823. Cells were transfected with Annexin A3-siRNA or control NS-siRNA, then were subjected to (A) wound healing assays to detect cell migrating activity, (B) transwell assays to detect cell invasion activity, (D) quantitative RT-PCR and (E and F) Western-blot assays to detect protein or mRNA expression levels of migration and invasion related genes. Representative results of transwell assay for cell invasion were shown in $\mathrm{C}$. The protein expression levels were represented as columns in F. ${ }^{*} \mathbf{P}<\mathbf{0 . 0 1}$ versus control group.

lated in prostate cancer, which promotes the occurrence and development of tumors. In the present study, we found that Annexin A3 expression was overexpressed in gastric cancers. A close association was observed between Annexin A5 and the histological differentiation of uterine cervical squamous cell carcinoma [27]. In addition, Annexin A3 has been reported as a negative regulator of adipocyte differentiation [28]. This study further demonstrated a negative correlation between Annexin A3 expression and the dedifferentiation of gastric cancer cells, indicating that Annexin A3 is likely to be a hopeful candidate as a noninvasive biomarker of tumor therapy.

Small interfering RNA (siRNA) introduces specific double-stranded RNA (dsRNA) into cells and results in sequence-specific gene silencing. With the advantages of specificity and high efficiency, the siRNA technique has become a common reverse genetics method of gene function research both in vivo and in vitro [29]. Suppression of endogenous Annexin A3 in BGC823 cells using siRNA, inhibited gastric cancer cell proliferation, promoted the expression of cell cycle negative regulators, p21 and p27, and suppressed the expression of cyclin D1, which enhances cell proliferation by promoting cell cycle progression from G1-S [32, 34]. We also found that expression of the cellular proliferation marker, PCNA, decreased after Annexin A3-siRNA treatment. These results indicate that Annexin A3 is involved in the proliferation of gastric cells. Similar results were found also in ovarian cancer [15].

Enhancement of invasion/migration abilities provides the basis for tumor metastasis, which is the result of malignant tumor progression [34]. Previous studies have reported that Annexin 1-deficient neutrophils exhibit enhanced transmigration in vivo [35]. Annexin A6 can modulate chick cranial 
neural crest cell emigration [36] and Annexin A2 can promote glioma cell invasion and tumor progression [37]. The present study showed that deletion of endogenous Annexin A3 reduced the invasion/migration of gastric cancer cells, indicating the positive role of Annexin A3 in gastric cancer cell invasion. Further studies on its molecular mechanisms demonstrated that the upregulation of TIMP-1 and TIMP-2, as well as the downregulation of TIMP-1 and TIMP-2, contribute to the impact of Annexin A3 on invasion and migration.

In conclusion, Annexin A3 expression increased and negatively correlated with cancer cell differentiation in gastric carcinoma. Silencing of endogenous Annexin A3 significantly inhibited cell proliferation, invasion, and migration by increasing the expression of p21, p27, TIMP-1, and TIMP-2, as well as decreasing the expression of PCNA, cyclin D1, MMP-1, and MMP-2. Although the detailed mechanisms underlying the effects of Annexin A3 on gastric cancer cells need to be elucidated in future studies, our present study suggests that Annexin A3 may play an important role in the development of gastric cancer as an oncogene, and the Annexin A3-siRNA approach may lead to new treatment options for gastric cancer.

Acknowledgements: This work was supported by grants to Yong Li from The National Natural Science Foundation of China (No.81072033); The Provincial Natural Science Foundation of Hebei Province (No. C2010000619); Extra Characteristic Foundation of Colleges and Universities in Hebei Province (NO. [2005] 52); Health Department of Hebei Province (NO. 20110460).

\section{References}

[1] PARKIN DM, BRAY F, FERLAY J, PISANI P. Global cancer statistics, 2002. CA Cancer J Clin 2005; 55: 74-108. http: //dx.doi.org/10.3322/canjclin.55.2.74

[2] ROUKOS DH. Genome-wide association studies and aggressive surgery toward individualized prevention, and improved local control and overall survival for gastric cancer. Ann Surg Oncol 2009; 16: 795-798. http: //dx.doi.org/10.1245/s10434009-0317-8

[3] WU K, NIE Y, GUO C, CHEN Y, DING J, et al. Molecular basis of therapeutic approaches to gastric cancer. J Gastroenterol Hepatol 2009; 24: 37-41. http: //dx.doi.org/10.1111/j.14401746.2008.05753.x

[4] LEUNG WK, WU MS, KAKUGAWA Y, KIM JJ, YEOH KG, et al. Asia Pacific Working Group on Gastric Cancer.Screening for gastric cancer in Asia: current evidence and practice. Lancet Oncol 2008; 9: 279-287. http: //dx.doi.org/10.1016/ S1470-2045(08)70072-X

[5] GRAVALOS C, JIMENO A. HER2 in gastric cancer: a new prognostic factor and a novel therapeutic target. Ann Oncol 2008; 19: 1523-1529. http: //dx.doi.org/10.1093/annonc/ $\underline{\operatorname{mdn} 169}$

[6] D'Ugo D, Rausei S, Biondi A, Persiani R. Preoperative treatment and surgery in gastric cancer: friends or foes? Lancet Oncol 2009; 10: 191-195. http: //dx.doi.org/10.1016/S14702045(09)70021-X
[7] CUNNINGHAM D, ALLUM WH, STENNING SP, THOMPSON JN, VAN DE VELDE CJ, et al. Perioperative chemotherapy versus surgery alone for resectable gastroesophageal cancer. N Engl J Med 2006; 355: 11-20. http: //dx.doi.org/10.1056/NEJMoa055531

[8] MACDONALD JS, SMALLEY SR, BENEDETTI J, HUNDAHL SA, ESTES NC, et al. Chemoradiotherapy after surgery compared with surgery alone for adenocarcinoma of the stomach or gastroesophageal junction. N Engl J Med 2001; 345: 725-730. http: //dx.doi.org/10.1056/ NEJMoa010187

[9] JEMAL A, BRAY F, CENTER MM, FERLAY J, WARD E, et al. Global cancer statistics. CA Cancer J Clin 2011; 61: 69-90. http: //dx.doi.org/10.3322/caac.20107

[10] BI S, LIU JR, LI Y, WANG Q, LIU HK, et al. gamma-Toeotrienol modulates the paracrine secretion of VEGF induced by cobalt $(И)$ chloride via ERK signaling pathway in gastric adenocarcinoma SGC-7901 cell line. Toxicology 2010; 274: 27-33. http: //dx.doi.org/10.1016/j.tox.2010.05.002

[11] FU X, WANG Q, CHEN J, HUANG X, CHEN X, et al. Clinical significance of miR-221 and its inverse correlation with p27Kip in hepatocellular carcinoma. Mol Biol Rep 2011; 38: 3029-3035. http: //dx.doi.org/10.1007/s11033010-9969-5

[12] WU N, LIU S, GUO C, HOU Z, SUN MZ. The role of annexin A3 playing in cancers. Clin Transl Oncol 2013; 15: 106-110. http: //dx.doi.org/10.1007/s12094-012-0928-6

[13] BAINE MJ, CHAKRABORTY S, SMITH LM, MALLYA $\mathrm{K}$, SASSON AR, et al. Transcriptional profiling of peripheral blood mononuclear cells in pancreatic cancer patients identifies novel genes with potential diagnostic utility. PLoS One 2011; 6: e17014. http: //dx.doi.org/10.1371/journal. pone.0017014

[14] BIANCHI C, BOMBELLI S, RAIMONDO F, TORSELLO B, ANGELONI V, et al. Primary cell cultures from human renal cortex and renal-cell carcinoma evidence a differential expression of two spliced isoforms of Annexin A3. Am J Pathol 2010; 176: 1660-1670. http: //dx.doi.org/10.2353/ ajpath.2010.090402

[15] JUNG EJ, MOON HG, PARK ST, CHO BI, LEE SM, et al. Decreased annexin A3 expression correlates with tumor progression in papillary thyroid cancer. Proteomics Clin Appl 2010; 4: 528-537.

[16] YAN X, YIN J, YAO H, MAO N, YANG Y, et al. Increased expression of annexin $\mathrm{A} 3$ is a mechanism of platinum resistance in ovarian cancer. Cancer Res 2010; 70: 1616-1624. http: //dx.doi.org/10.1158/0008-5472.CAN-09-3215

[17] SHEKOUH AR, THOMPSON CC, PRIME W, CAMPBELL F, HAMLETT J, et al. Application of laser capture microdissection combined with two-dimensional electrophoresis for the discovery of differentially regulated proteins in pancreatic ductal adenocarcinoma. Proteomics 2003; 3: 1988-2001. http: //dx.doi.org/10.1002/pmic.200300466

[18] LIU YF, XIAO ZQ, LI MX, LI MY, ZHANG PF, et al. Quantitative proteome analysis reveals annexin A3 as a novel biomarker in lung adenocarcinoma. J Pathol 2009; 217: 54-64. http: //dx.doi.org/10.1002/path.2429 
[19] TONG SW, YANG YX, HU HD, AN X, YE F, et al. Proteomic investigation of 5-fluorouracil resistance in a human hepatocellular carcinoma cell line. J Cell Biochem 2012; 113: 1671-1680.

[20] NIIMI S, HARASHIMA M, GAMOU M, HYUGA M, SEKI T, et al. Expression of Annexin A3 in Primary Cultured Parenchymal Rat Hepatocytes and Inhibition of DNA Synthesis by Suppression of Annexin A3 Expression Using RNA Interference. Biol Pharm Bull 2005; 28: 424-428. http: //dx.doi. org/10.1248/bpb.28.424

[21] KAMANGAR F, DORES GM, ANDERSON WF. Patterns of cancer incidence, mortality, and prevalence across five continents: defining priorities to reduce cancer disparities in different geographic regions of the world. J Clin Oncol 2006; 24: 2137-2150. http: //dx.doi.org/10.1200/JCO.2005.05.2308

[22] MOSS SE, MORGAN RO. The annexins. Genome Biol 2004; 5: 219. http: //dx.doi.org/10.1186/gb-2004-5-4-219

[23] MUSSUNOOR S, MURRAY GI. The role of annexins in tumour development and progression. J Pathol 2008; 216: 131-140. http: //dx.doi.org/10.1002/path.2400

[24] HAYES MJ, MOSS SE. Annexins and disease. Biochem Biophys Res Commun 2004; 322: 1166-1170. http: //dx.doi. org/10.1016/j.bbrc.2004.07.124

[25] BIAOXUE R, XILING J, SHUANYING Y, WEI Z, XIGUANG C, et al. Upregulation of Hsp90-beta and annexin A1 correlates with poor survival and lymphatic metastasis in lung cancer patients. J Exp Clin Cancer Res 2012; 31: 70. http: //dx.doi. org/10.1186/1756-9966-31-70

[26] JUNG EJ, MOON HG, PARK ST, CHO BI, LEE SM, et al. Decreased annexin A3 expression correlates with tumor progression in papillary thyroid cancer. Proteomics Clin Appl 2010; 4: 528-537.

[27] Li X, Chen L, LIANG XJ, GAO YF, WANG XJ, et al. Annexin A5 protein expression is associated with the histological differentiation of uterine cervical squamous cell carcinoma in patients with an increased serum concentration. Mol Med Report 2012; 6: 1249-1254.

[28] WATANABE T, ITO Y, SATO A, HOSONO T, NIIMI S, et al. Annexin A3 as a negative regulator of adipocyte dif- ferentiation. J Biochem 2012; 152: 355-363. http: //dx.doi. org $/ 10.1093 / \mathrm{jb} / \mathrm{mvs} 084$

[29] HANNON GJ. RNA interference. Nature 2002; 418: 244-251. http: //dx.doi.org/10.1038/418244a

[30] Lin Ll, HUANG HC, JUAN HF. Revealing the molecular mechanism of gastric cancer marker annexin a 4 in cancer cell proliferation using exon arrays. PLoS One 2012; 7: e44615. http: //dx.doi.org/10.1371/journal.pone.0044615

[31] KHAU T, LANGENBACH SY, SCHULIGA M, HARRIS T, JOHNSTONE CN, et al. Annexin-1 signals mitogen-stimulated breast tumor cell proliferation by activation of the formyl peptide receptors (FPRs) 1 and 2. FASEB J 2011; 25: 483-496. http: //dx.doi.org/10.1096/fj.09-154096

[32] ABBAS T, DUTTA A. p21 in cancer: intricate networks and multiple activities. Nat Rev Cancer 2009; 9: 400-414. http: //dx.doi.org/10.1038/nrc2657

[33] LI N, ZHONG X, LIN X, GUO J, ZOU L, et al. Lin-28 homologue A (LIN28A) promotes cell cycle progression via regulation of cyclin-dependent kinase 2 (CDK2), cyclin D1 (CCND1), and cell division cycle 25 homolog A (CDC25A) expression in cancer. J Biol Chem 2012; 287: 17386-17397. http: //dx.doi.org/10.1074/jbc.M111.321158

[34] BROUSTAS CG, ZHU A, LIEBERMAN HB. Rad9 Contributes to Prostate Tumor Progression by Promoting Cell Migration and Anoikis Resistance. J Biol Chem 2012; 287: 41324-41333. http: //dx.doi.org/10.1074/jbc.M112.402784

[35] CHATTERJEE BE, YONA S, ROSIGNOLI G, YOUNG RE, NOURSHARGH S, et al. Annexin 1-deficient neutrophils exhibit enhanced transmigration in vivo and increased responsiveness in vitro. J Leukoc Biol 2005; 78: 639-646. http: //dx.doi.org/10.1189/jlb.0405206

[36] WU CY, TANEYHILL LA. Annexin a6 modulates chick cranial neural crest cell emigration. PLoS One 2012; 7: e44903. http: //dx.doi.org/10.1371/journal.pone.0044903

[37] ZHAI H, ACHARYA S, GRAVANIS I, MEHMOOD S, SEIDMAN RJ, et al. Annexin A2 promotes glioma cell invasion and tumor progression. J Neurosci 2011; 31: 14346-14360. http: //dx.doi.org/10.1523/JNEUROSCI.3299-11.2011 